\title{
Evaluation of local injection of Acrylic Denture Base Material in \\ Bucks spermatic cord.
}

\author{
Muna Ridha Al-Dahhan.
}

College of Vet. Med, Baghdad University- Iraq.

\section{Accepted. 9/12/2009.}

\section{Summary}

This study was performed to identify gross and histopathology changes which can be occur in testis and spermatic cord following injection of Acrylic Dental Base Material inside spermatic cord, the agent is widely present, cheep, quick, highly solid and used as a substance of chemical castration. It was injected inside spermatic cord of 15 healthy adult bucks in the ratio of 3:1 bilaterally ; Treated animals where divided randomly in to 5 groups depending on time for gross and histopathology examination after injected with the material. Animals were followed up for 7 days, 14 days, 30 days, 60 days, and 150 days after injection. Result showed good and immediate hardening after 20-25 min. of injected material. Gross examination of testis after 7-14 days of material injection didn't showed marked changes. While after 30 -60 days showed thickening of tunica vaginals which was easy isolated, and the testis was atrophied .And after 150 days showed disappear of testis structures with more atrophied. Histopathology changes of testis characterized by reduce rate of spermatogenesis, thickening of basement membrane, inflammation was reduce in late stage and deposition of fibrous tissue. While the mean feature of histopathology changes of spermatic cord include, infiltration of inflammatory cells, then fibrosis which lead to complete contraction and obstruction of it from first week after injection.

\section{تقييم حقن مادة قالب قاعدة الأسنان في الحبل المنوي لذكور المعز.}

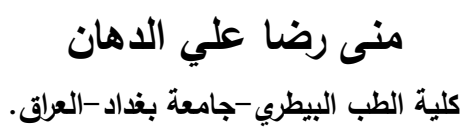

الخلاصة

صمدت هذه الدراسة للتعرف على التغيرات العيانية والنسجية للخصية والحبل المنوي والتي ممكن أن تحدث بعد حقن

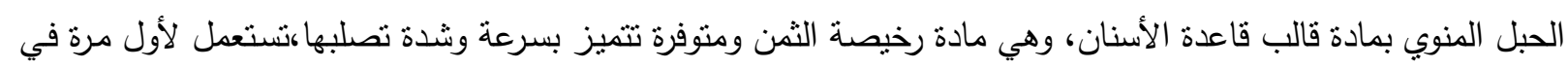

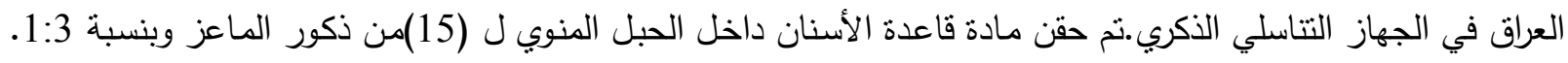

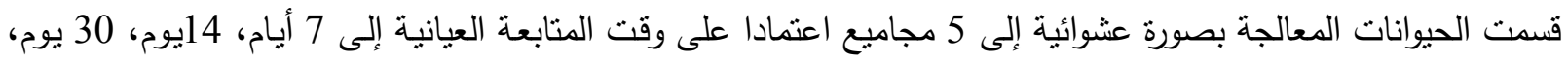

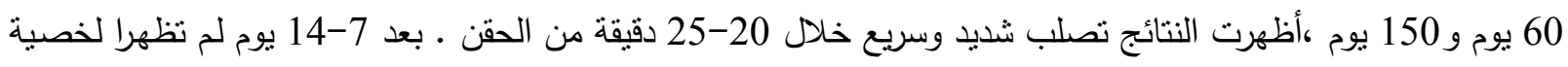

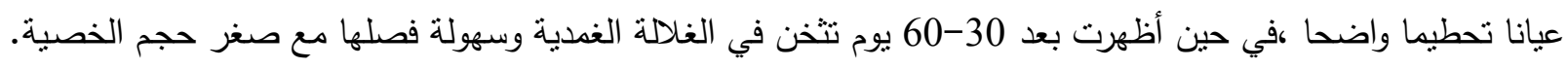

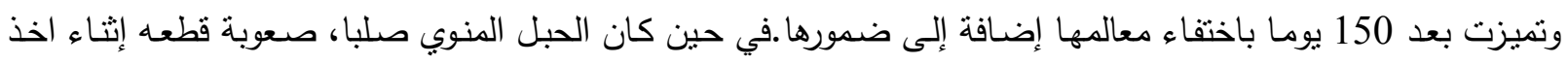
المقاطع النسجية المرضية مـع وجود النصاقات بين كيس الصفن والحبل المنوي في مكان حقن المادة.أظهرت التغيرات

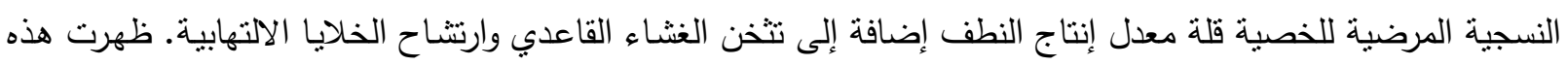
التغيرات منذ السبعة أيام الأولى من الحقن.وبالنسبة للتغيرات النسجية التي حصلت للحبل المنوي فقد تنتلت بارتنـاح خلايا

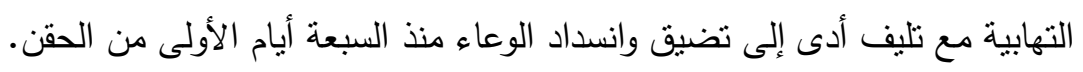




\section{Iraqi Journal of Veterinary Medicine Vol. 34, No. 1, 2010}

\section{Introduction}

Castration considered as earliest surgical method in veterinary medicine. It means remove of male sex glands or stop there functions, which can be performed at any time; some allow development of certain desirable physical characteristics. It should be ascertained that the animal is healthy and that both testis are descended (1). It is important to improve quality and quantity of wool and meat, fatting animals before slaughter, also used for treatment of inguinal or scrotal hernia, and chronic inflammation of testis, to avoid risk of injury as a result of sexual related behaviors (2). There are two main methods of castration non surgical like rubber rings, Bardizzo, Immunosterilisation, Chemosterilants, and Surgical (open and closed methods) (3and4).Chemosterilants are chemicals that cause permanent or temporary sterility in either sex reducing the number of offspring or altering the fertility of offspring produced (5) .Surgical castration took longer time than chemical, cause more acute pain, healing took longer time than chemical, but chemical castration characterized by minor hemorrhage, infection unlikely, and behavior is largely unaffected by the technique, no surgical equipment was needed to carry out the procedure (2). There are some substance used in chemical castration like Alphachlorohydrins ,Zinc arginine, Formalin, Cannabis extract, Salas dine(C27 H 4302 N), 3Chloro-1,2-propanediol, Danazol ,Calcium chloride, Cadmium chloride, Lactic acid ,and others, which gave different result some were good and others were not(6,7and8).

Acrylic Dental Base Material which is widely used in denture because of the simplicity and lower cost of it. The material have low but adequate strength, being fairly flexible, brittle and soft with a reasonably high resistance fatigue fracture, low thermal conductivity and heat distortion temperature (9). Fairly high polymerization shrinkage, high water sorption but low water solubility, good resistance to attack by solvents, no adhesion to metal, good color stability and tissue compatibility, moderate wet ability by water , and no taste or odor (10). The aim of this study was to evaluate the use of this material which injected in the spermatic cord and its surrounding tissue to induce permanent occlusion and damaging and study the gross and histopathological changes in the spermatic cord and testis (11).

\section{Materials and methods}

Fifteen healthy adult bucks were used. The animals were sedated with xylazine $0.06 \mathrm{mg}$ $/ \mathrm{kg}$ B.W .intravenously [12].Animals prepared under aseptic technique and placed in lateral recumbency, and the spermatic cord was grasped with towel clips from proximal and distal part to prevent its movement(Fig. A). Then Bull Dog forceps was applied in the proximal part near the body to prevent passing of chemical material toward the body (Fig.B).Acrylic denture base material in aratio(3:1 liquid and powder) (table,1) was injected at a dose of $(10-15 \mathrm{cc})$ in each spermatic cord (Fig.C,D,E). The material become solid in about 20-25min (Fig.F), bulldog forceps removed after solidation. Animals were followed grossly and histopathologically for $7,14,30,60$ and 150 days depending upon time of routine castration.

Components of the powder and liquid of an Acrylic Denture Base Material (table, 1) [13].

\begin{tabular}{|l|l|}
\hline Powder & Liquid \\
Poly(methyl methacrylate)or polymer & Methyl methacrylate or monomer \\
Organic peroxide initiator & Hydroquinone inhibitor \\
Titanium dioxide to control translucency & Dimethacrylate or cross-linking agent \\
$\begin{array}{l}\text { Inorganic pigments for color } \\
\text { Dyed synthetic fibers for esthetics }\end{array}$ & Organic amine acceleratort \\
\hline
\end{tabular}




\section{Iraqi Journal of Veterinary Medicine Vol. 34, No. 1, 2010}
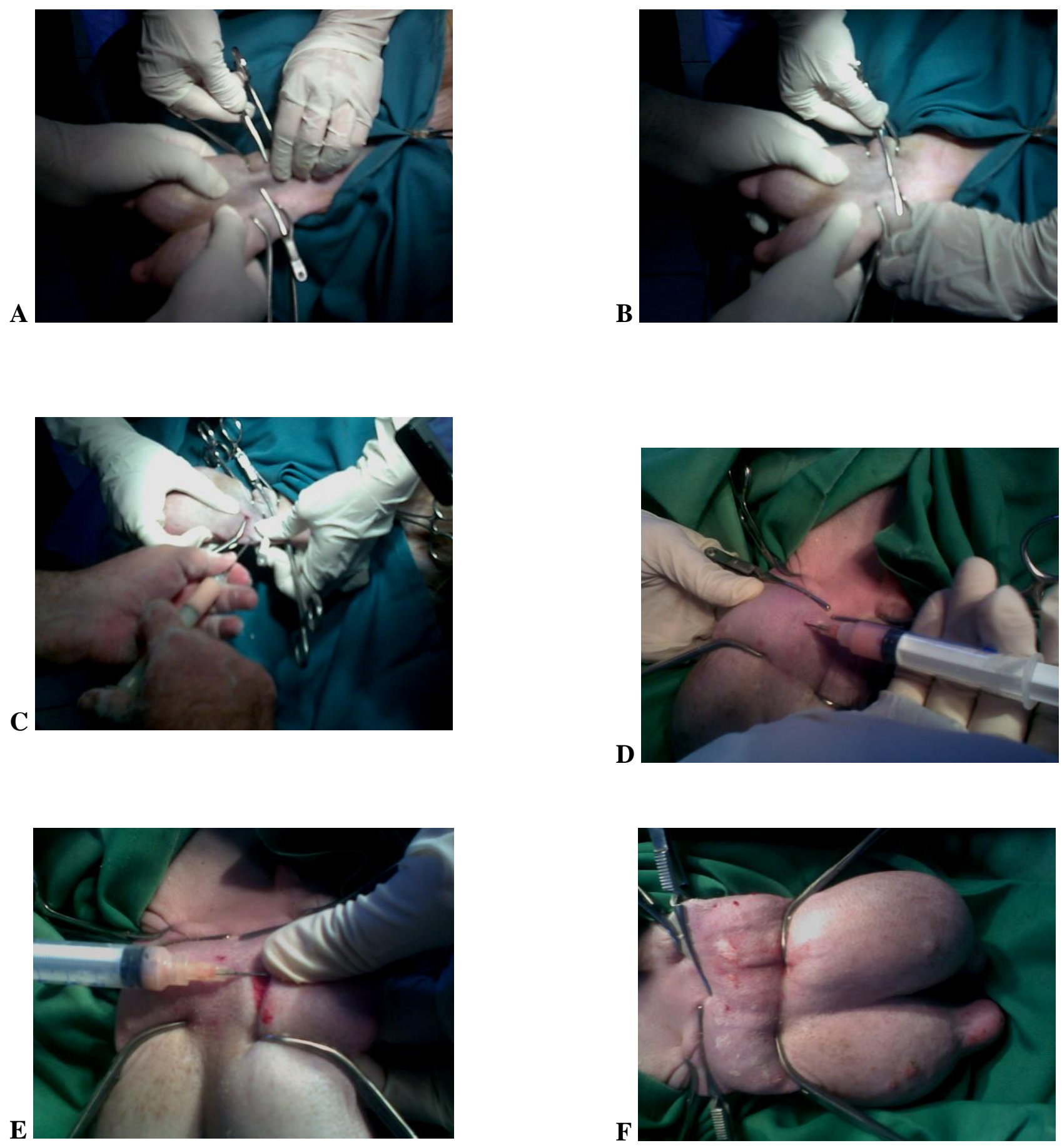

Fig: Photograph show prepation of the area and procedure of injection.

A-Shows the application of towel clips and bulldog forceps.B -Bull dog forceps applied in the same line.

C- Injection of acrylic denture base material into spermatic cord.D-Other site of injection.

E -Full all spermatic cord.F -Solidation of material and hardening of spermatic cord. 


\section{Iraqi Journal of Veterinary Medicine Vol. 34, No. 1, 2010}

\section{Results}

Gross examination of testis and spermatic cord.

A- After one week tunica vaginalis was thicken.

B- After two weeks tunica vaginals was green in color.

C- After one month tunica vaginalis was more thickened,

D- After two months changes of testis shape and structures.

E1, E2- Testis after five months no bleeding during routine castration. infiltration of the ADBM between damaged semniferous tubules.

A

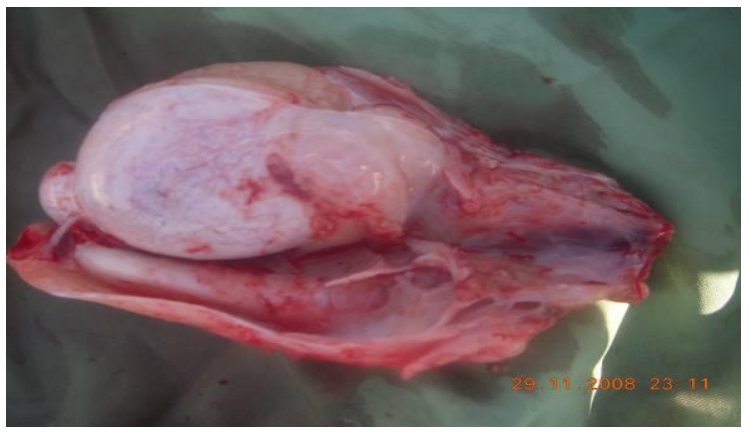

C



E1

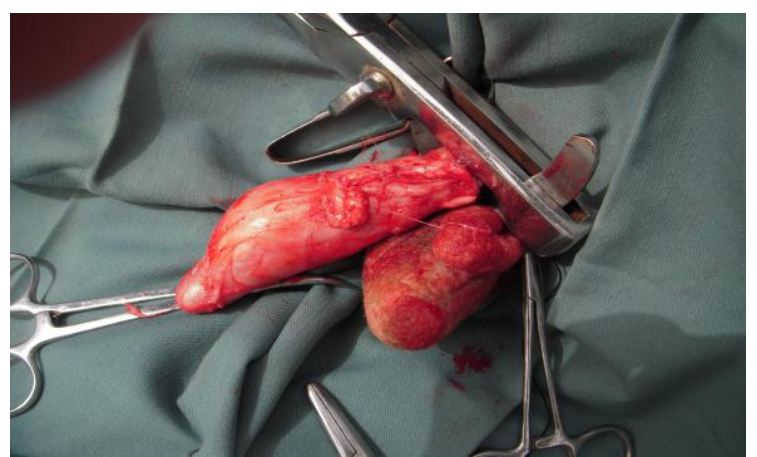

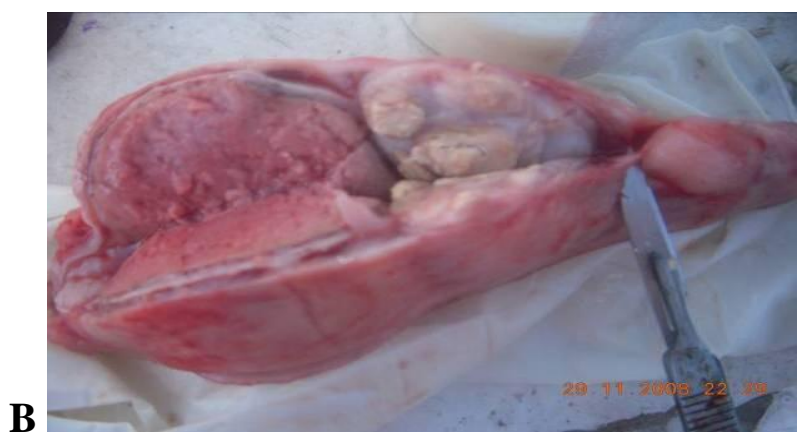

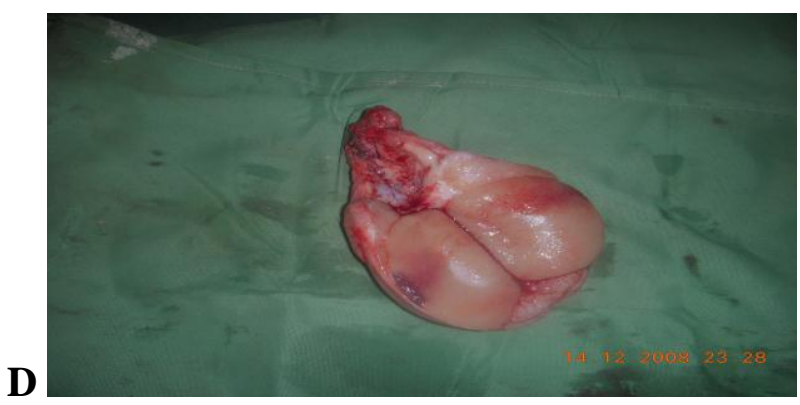

E2

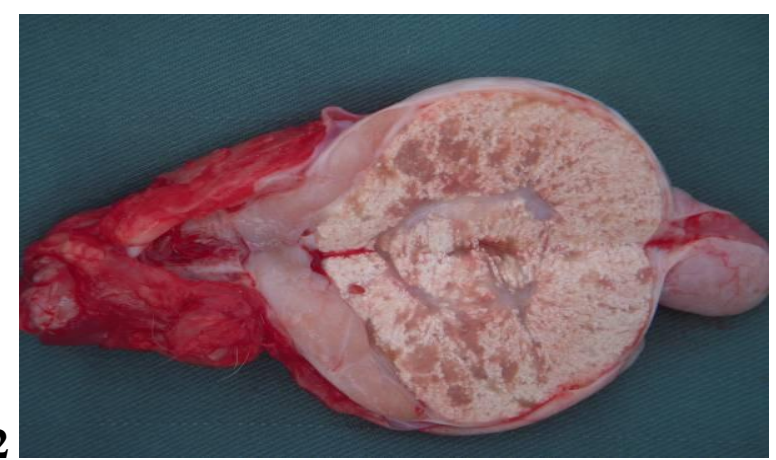




\section{Iraqi Journal of Veterinary Medicine Vol. 34, No. 1, 2010}

Histopathology Changes of testis after injection.

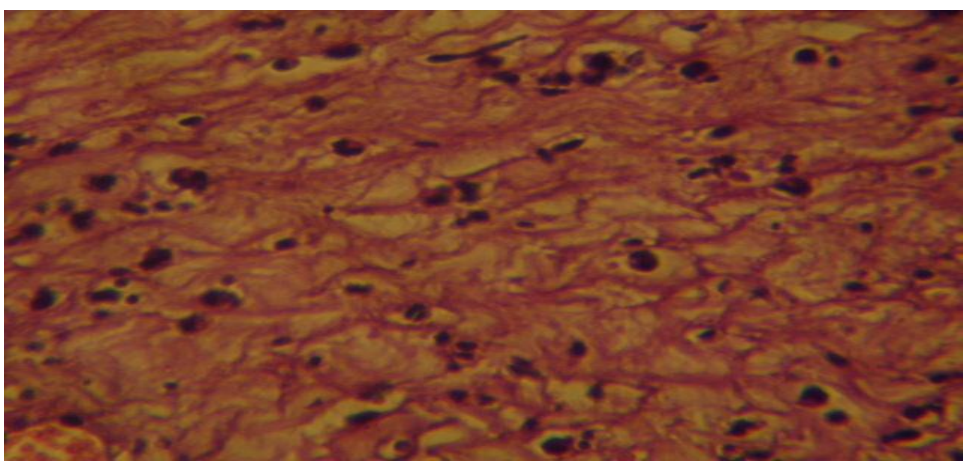

7 Days after injection: Increase in thickness of the albogeniar layer due to proliferation of fibrous connective tissue and inflammatory cells infiltration particularly macrophages and neutrophils.

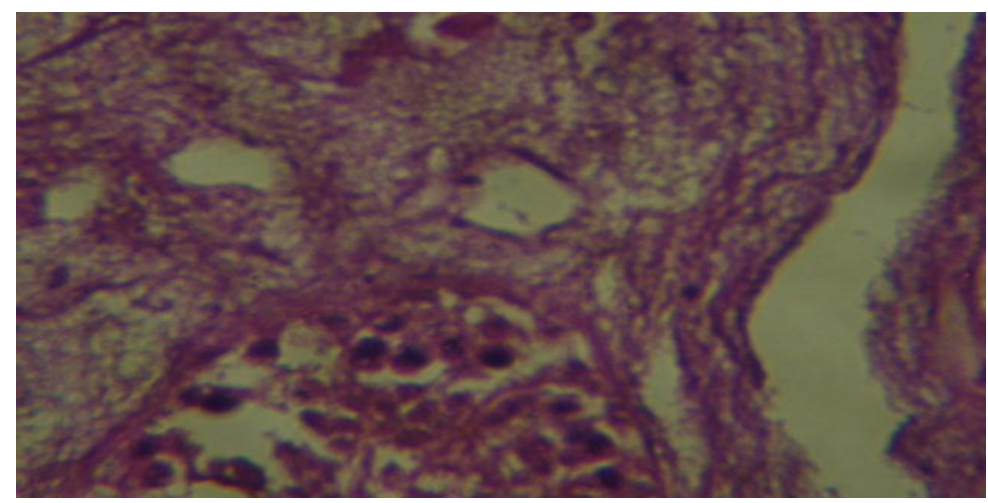

30 Days after injection: The interstitial between seminiferous tubules characterized by thickness due to fibrin net deposition and fibrous connective tissue proliferation which lead to atrophy of seminiferous tubules. The seminiferous tubule showed increase in the thickness of basement membrane, evacuation of sertoli cells and necrosis and degeneration of spermatogonea.



14 Days after injection Increase thickening of seminiferous tubules due to fibrous connective tissue proliferation, evacuation of sertoli cells and necrosis and absent of spermatogonia ,only tissue depprise are present in the lumen of seminefarious tubules .

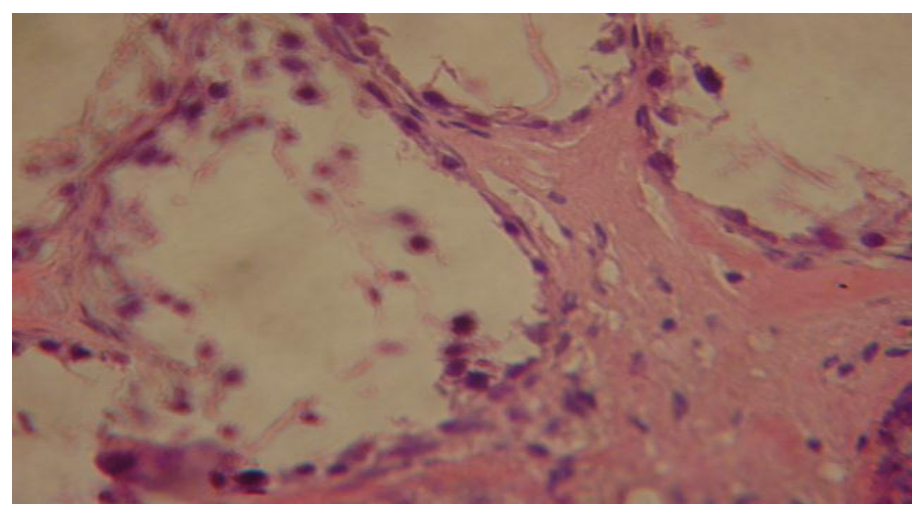

60 Days after injection: Histopathologic examination shows increase thickness of interstitial tissue due to fibrosis as well as loss all layers of the seminiferous tubules, only remain basement membrane with few cells appear in the center of seminiferous tubules. 


\section{Iraqi Journal of Veterinary Medicine Vol. 34, No. 1, 2010}

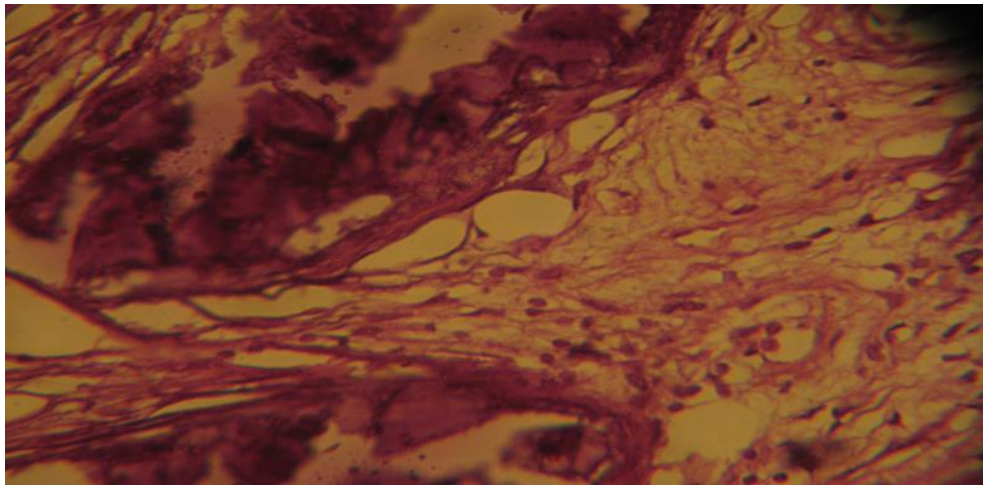

150 Days after injection: Histopathologic section refers to fibrosis of interstitial tissue with necrosis and calcium deposition in the seminiferous tubules.

Histopathology Changes of spermatic cord.

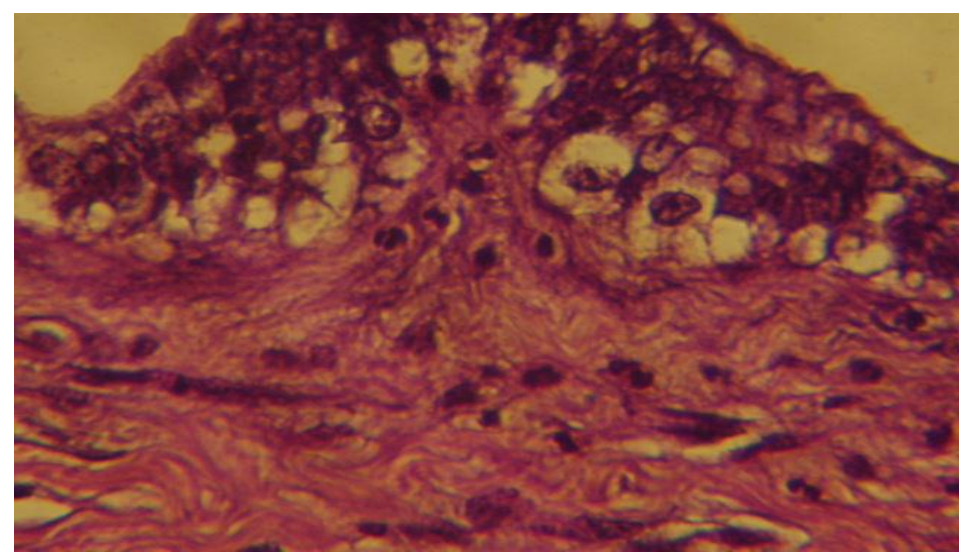

7 Days after injection: Hyperplasia of the epithelial lining of the mucosa which show evacuation of there cytoplasm as well as proliferation of fibrous connective tissue in the wall of spermatic cord which infiltrated by inflammatory cells mainly neutrophils and macrophages

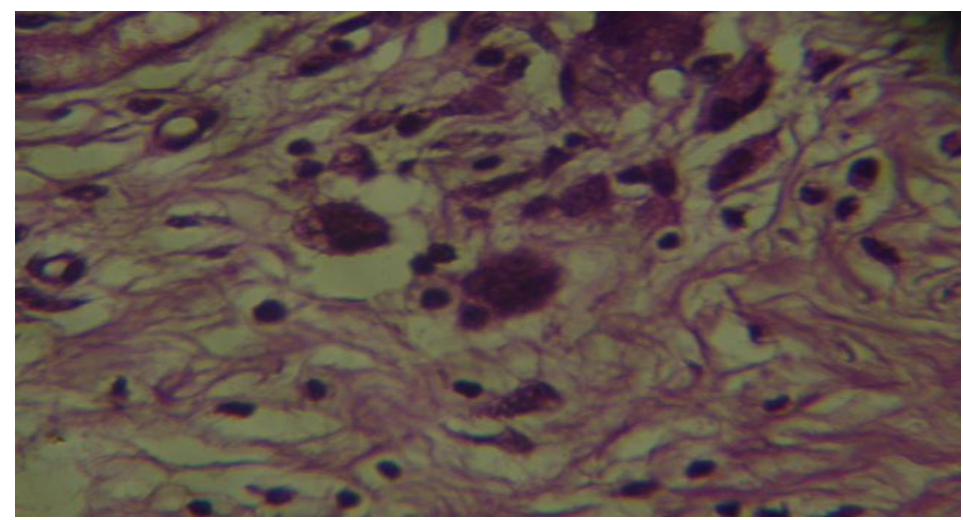

30 Days after injection: There is fibrosis of the interstitial tissue with inflammatory cells infiltration macrophage lymphocyte, as well as giant cells and myofibroblasts.

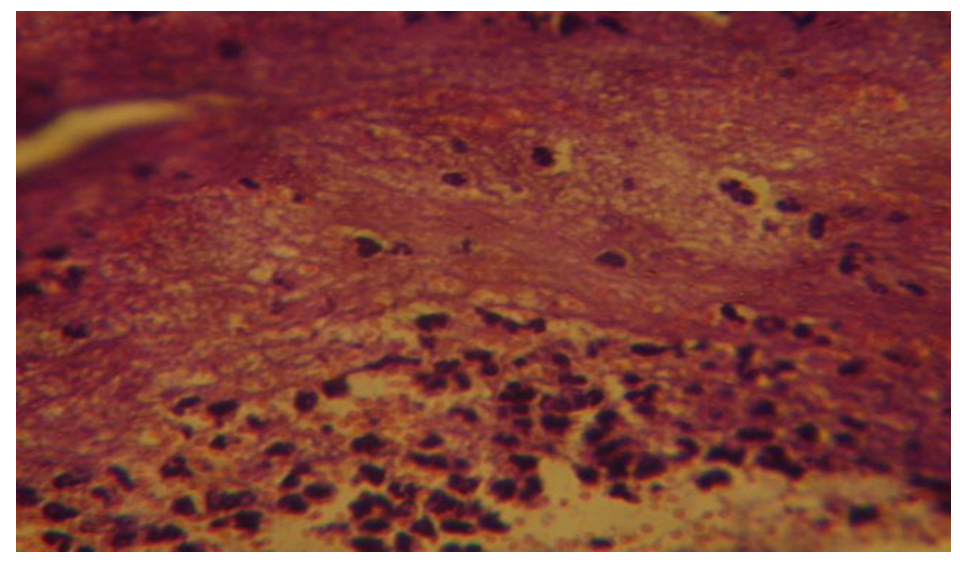

14 Days after injection: The lesion characterized by fibrin deposition in the interstitial tissue of the spermatic cord with inflammatory cells infiltration mainly neutrophils and macrophages.

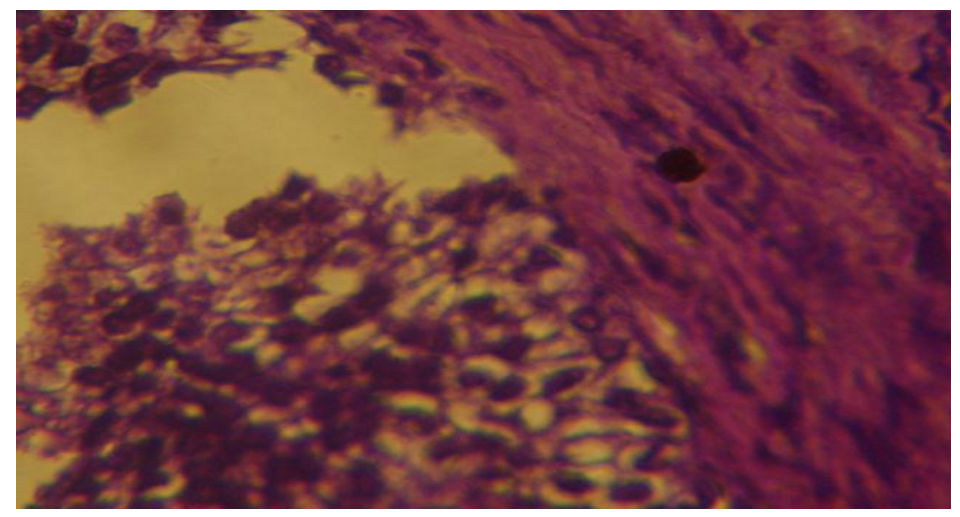

60 Days after injection: The lumen of spermatic cord packed with dead sperm and inflammatory cell as well as sloughing and desquamation of epithelial cells lying of mucosa. 


\section{Iraqi Journal of Veterinary Medicine Vol. 34, No. 1, 2010}

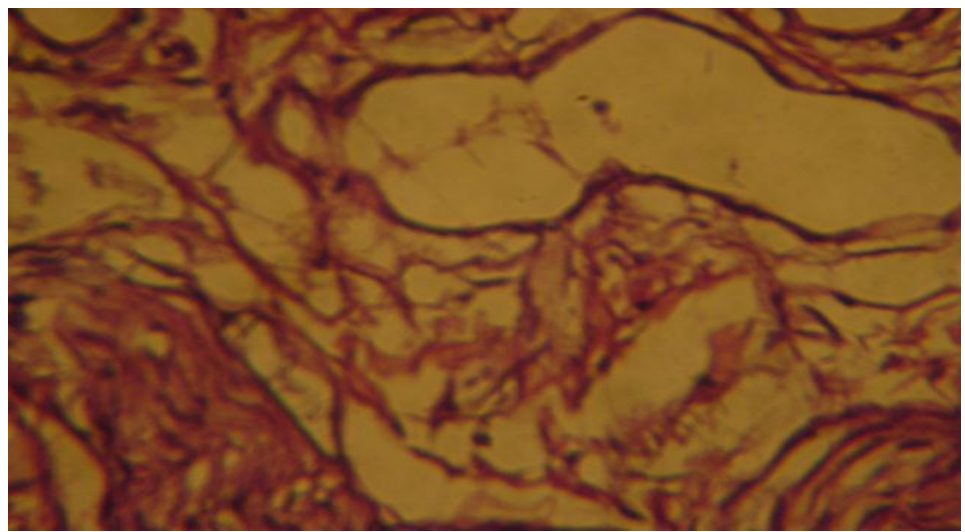

150 Days after injection: Shows fibrous connective tissue proliferation in the interstitial tissue which lead to deformity or excluded the spermatic cord.

\section{Discussion}

The Acrylic Dental Base material used for injected in spermatic cord. Results showed quick and hard solidation of the material in about 20-25 min. after injection this time depend upon ratio of its mixture which was about 3:1, the injected material infiltrate within and in between composition of spermatic cord then cause complete obstruction. This solid material lead to pressure on its artery, veins, lymphatic, vas deferens, internal creamaster muscle and visceral layer of the tunica vaginalis, and its surrounding tissue and cause less stress [2]. The site of injection become worm about $10-15 \mathrm{~min}$. after injection this local rise of temperature was related to the amount of monomer used and the ratio of mixing liquid to powder [9]. This local effect regarded a desirable effect as antiseptic effect by heat and minimized the possibility of infection which may be induced during injection [13].Manual palpation of spermatic cord reveled very hard, solid and difficult to cut when trying to take samples for histological examination, also there was adhesion at sites of injection, there wasn't any bleeding below site of injection during castration by emasculator which means there was complete occlusion of spermatic cord.

Gross examination of testis after 7-14 days reviled mild changes or damage as well as testicular swelling, due to inflammation characterized by congestion and edema result un increase force that tend to move fluid from intravascular compartment into interstitial tissue [14]. , and thickening of tunica vaginalis. While after 30-60 days testis became pale in color and small in size. Tunica vaginalis was easy isolated because of its thickening. After 150 days testis were severe damaged, complete disappear of tubules, and more atrophy of it .Testicular atrophy may be due to diminished blood supply, loss of innervations and loss of endocrine stimulation result in loss of active spermatogenesis [14].

Histopathology changes of testis appear during 7 days of injection then became more severe following this period of time, till last group which showed complete damage of testis . While spermatic cord examination showed obstruction of it from first week.

Injections of Acrylic Dental Base Material inside spermatic cord lead to complete obstruction as well as severe damage and atrophy of testis, so it is considered as good method of chemical castration without any risk of operation, anesthesia, bleeding or need of surgical instrument. So we performed this technique for its quick, safe, and perfect obstruction of spermatic cord which leads to castration [15].

\section{References}




\section{Iraqi Journal of Veterinary Medicine Vol. 34, No. 1, 2010}

1. Turen AS and Mcilwraith CW (1989). Techniques in large animal surgery. $2^{\text {nd }}$.ed. Lea and Febiger. Philadelphia London Pp: 289-291.

2. Michael (2002). Pain and its control. In: Routine husbandry procedures in sheep and cattle. ACT Animal Welfare Advisory Committee. P: 3.

3. Tuyttens FA(1998). Fertility control: An option for non-lethal control of wild carnivores. Animal Welfare, 7:339-364.

4. Kent JE MolonyV and Graham MJ (1998). Comparison of methods for the reduction of acute pain produced by rubber ring castration or tail docking of week old lambs. Vet $\mathrm{J}$ 155:87-97

5. Fayrer-H R (2000). Immunocontrol in dogs. Ani. Reprod Sc.i 60-61:365-373.

6. Fahim MS Wang Sutcu MF Fahim Z and Youngquist RS (1993). Sterilization of dog with intra-epididymal injection of zinc argin.Contraception, 47(1):107-122.

7. Morrant AJ (1959).Non surgical casteration Vet J. 35:268 Cited by: Pearson GH (1980)..

8. Freeman C and Coffey DS (1973). Sterility in male animals induced by injection of chemical agents into the vas deferens. Ferti Steri. 24:884.

9. Craig RG (1991). Denture materials and acrylic base material, Current Opinionin Dentistry, $1(2): 235$.

10. Brauer GM (1977). Polymers in dentistry. In Craig RG edi Dental materials review ann arbor MI University of Michigan School of Dentistry. P:103

11. Dootz ER Koran A and Craig RG: (1993). Physical property comparison of soft denture lining material as a function of accelerated aging Prosthetic Dent,69:114.

12. Riebold TW Geiser D Rand Coble DO :(1995). Large animal anesthesia principle and techniques Eds Ames Lowa. P:34

13. Kawano F (1992). Comparison of bond strength of six soft denture liners to denture base resin Prosthetic Dent. 68:368.

14. Alkadi KH (2008).Castration of the bucks, via comparative study of using single and double ligation of the spermatic cord. Coll Vet Med Univ Bagh.Iraq..

15. Dombromyskyj P, Fleck Nell PA, Las Cells BD, Pascoe PJ Taylor P and Waterman PA (2000). Management of postoperative and acute pain. In Fleck Nell P and Waterman Pearson A. (Eds) Pain Management in Animal WB Saunders. Pp 81-146. 